\title{
Prevalence and Severity of Dental Caries and Fluorosis in 8 Year-old Children With or Without Fluoride Supplementation
}

\author{
Prevalencia y Severidad de Caries Dental y Fluorosis en Niños \\ de 8 Años cono Sin Suplementos de Flúor
}

Ismael Yévenes; Gisela Zillmann²; Tamara Ellicker²; Pamela Espinoza²; Gloria Xaus²; Patricia Cisternas²; Bárbara Cárdenas¹ \& Pedro Castillo1

YÉVENES, I.; ZILLMANN, G.; ELLICKER, T.; ESPINOZA, P.; XAUS, G.; CISTERNAS, P.; CÁRDENAS, B. \& CASTILLO, P. Prevalence and severity of dental caries and fluorosis in 8 year-old children with or without fluoride supplementation. Int. J. Odontostomat., 13(1):46-50, 2019.

ABSTRACT: One of the most effective and studied measures in the prevention of caries is the use of fluoride, which has the property to reduce their incidence and severity. In Chile, $75 \%$ of the population receives it the drinking water. In 1984, WHO recommended the use of milk as an alternative vehicle. In Chile, the Fluoridated School Feeding Program (FSFP) was introduced in 1994, using this alternative in rural areas without fluoride in water. The objective of the study was to compare prevalence and severity of dental caries and dental fluorosis in 8-year-old children of four state schools: two with fluoride supplementation in drinking water or milk and two without any fluoride program. Epidemiological, descriptive, comparative, observational and cross-sectional study with a sample of 1408 -year-old children, with no systemic diseases and who had lived in the same place since birth: 50 schoolchildren from an area with fluoridated water; 40 from an area with fluoridated milk and 50 from a zone without supplementation of $F$. The percentage of caries-free children was obtained with the methodology described by the WHO, for severity the dmft and DMFT indexes were used. To quantify the prevalence and severity of dental fluorosis, Dean Index was used. $38 \%$ of the children were caries-free in the community with fluoridated water (CFW); $0 \%$ in the community with fluoridated milk (FSFP) and $10 \%$ in the community with no fluoride program established (CNF). The difference between CFW with CNF is statistically significant $(p<0.05)$. The prevalence of fluorosis is significantly higher for CFW (48.8 \%) than FSFP (35\%) and CNF (16\%). Conclusion: The contribution of fluoride in drinking water causes a decrease in the prevalence and severity of dental caries in children of 8 years of age, and an increase in the prevalence of dental fluorosis.

KEY WORDS: Dental caries; Fluorosis; Children; Fluoride supplementation.

\section{INTRODUCTION}

Dental caries is a multifactorial, polymicrobial, localized and progressive disease that affects hard tissues on teeth and constitutes a serious public health issue in all countries, including developed ones (Carounanidy \& Sathyanarayanan, 2009; Quock, 2017; Zanella-Calzada et al., 2018). In Chile, this pathology has the highest prevalence amongst children and adolescents (Ministerio de Salud, 2010).

One of the most efficient and effective measures studied in the prevention of caries is the use of fluoride, which has the property of reducing dental caries incidence and progression of incipient lesions. WHO declared that it modifies enamel structure and increases its resistance, decreasing the risk of dental caries. For about 3 decades, fluoride has been considered the key factor in the decline of dental caries in both children and adults. The incorporation of fluoride into drinking water began in 1945-46 in the USA and Canada (Yeung et al., 2007; U.S. Department of Health and Human Services Federal Panel on Community Water Fluoridation, 2015; Iheozor-Ejiofor et al., 2015; McLaren et al., 2017). Later in Latin America, several fluoridation programs were implemented through water supply and added to table salt. In Chile, water fluoridation is a process that has been uninterruptedly applied since it was implemented in some cities in 1953 and mostly

\footnotetext{
${ }^{1}$ Institute for Research in Dental Sciences, Faculty of Dentistry, University of Chile, Santiago, Chile.
}

${ }^{2}$ Department of Pediatric Dentistry, Faculty of Dentistry, University of Chile, Santiago, Chile. 
YÉVENES, I.; ZILLMANN, G.; ELLICKER, T.; ESPINOZA, P.; XAUS, G.; CISTERNAS, P.; CÁRDENAS, B. \& CASTILLO, P. Prevalence and severity of dental caries and fluorosis in 8 year-old children with or without fluoride supplementation. Int. J. Odontostomat., 13(1):46-50, 2019.

spread in other cities in the country since 1984. Currently, approximately $72 \%$ of the national population has fluoride artificially added into tap water and in rural places where no tap water is available, fluoride is provided though Fluoridated School Feeding Program into milk (FSFP) (Romero et al., 2017).

At the same time, some studies stated an increase in prevalence of dental fluorosis. Enamel is susceptible when its pre-eruptive maturation has not been completed (Otten et al., 2006). Historically, a predominance of very mild and mild forms of dental fluorosis has been considered a minor consequence in relation to the substantial protection against dental caries by ingesting tap water with an optimum concentration of fluoride, natural or adjusted (Otten et al.; Hujoel et al., 2009; Do et al., 2014).

Currently, $83 \%$ of the urban population has access to fluoridated drinking water, corresponding to $72 \%$ of the total population. The Ministry of Health indicates the optimum fluoride concentration that water must contain in each region, in order to achieve the caries prevention objectives, minimizing risks. The optimal concentration ranges between 0.6 and $1.0 \mathrm{mg} / \mathrm{L}$ (Ministerio de Salud, 2008). It is necessary to know the current oral health situation in school population and evaluate the systemic intake of this element. The purpose of this work was to compare the effect of fluoride ingested through water and milk on the prevalence of caries and fluorosis in 8-yearold schoolchildren in schools from communities with fluoridated program in water (CFW) or milk (FSFP) and with no fluoridation program (CNF).

\section{MATERIAL AND METHOD}

Study design and study population. It is an observational, descriptive, comparative, crosssectional epidemiological study. The population studied were 8-year-old children from a school in the commune of Independencia, whose drinking water is fluoridated since 1996 with $0.6 \mathrm{mg} / \mathrm{L}$, from two schools in the commune of Maipú, whose drinking water is without fluoride and from a school in the rural area of Pirque, whose students receive fluoride through milk over FSFP. The schools are public establishments belonging to the Metropolitan Region and the selected communes have a similar socioeconomic stratification (lower class).
A sample was drawn up for the convenience of 140 children in total, 50 children from CFW, 50 children from CNF and 40 children from FSFP. All the children selected were 8 years old and lived in the corresponding school community, from birth. The parents of the students accepted the participation of the children in the project through an informed consent. Inclusion criteria were 8 year-old healthy volunteers from both sexes and residents from where they studied since birth.

Prevalence and severity of dental caries and dental fluorosis. Since these were children under mixed dentition stage, the dmft index was used for temporary dentition, and DMFT for permanent dentition to study carious lesions.

Dean index was used to quantify the prevalence and severity of dental fluorosis, using the 2 most affected teeth, and classified from 0 to 5 , which is also the WHO recommended index for epidemiologic studies (World Health Organization, 2013).

The examiner was subjected to calibration, obtaining a Kappa inter index of 0.93 and intra of 0.87 . The exams were conducted in a classroom, placing the child lying on a desk. The examiner was located at the head of the child, a lamp on one side and the working areas ("clean", "dirty", and "administrative" areas) delimited with different chairs or desk tables. The clinical file used was a modification of the clinical record of the Oral Health Survey established by World Health Organization (2013).

\section{RESULTS}

Caries-free children were $38 \%$ in CFW; $0 \%$ in FSFP and $10 \%$ in CNF. There is a statistically significant difference between caries-free children in CWF and those in CNF and between caries-free children in CWF and children under FSFP $(p<0.05)$ (Table I). There was no statistically significant difference in dmft index comparing CNF and FSFP, but there was when comparing DMFT index between CNF and FSFP. The average of sealed pieces in both dentitions is higher in FSFP than in the other communities $(p<0.05)$ (Table II).

In Figure 1, it can be seen that the community with fluoridated water (CFW) and the community under fluoridated school feeding program (FSFP) have a 


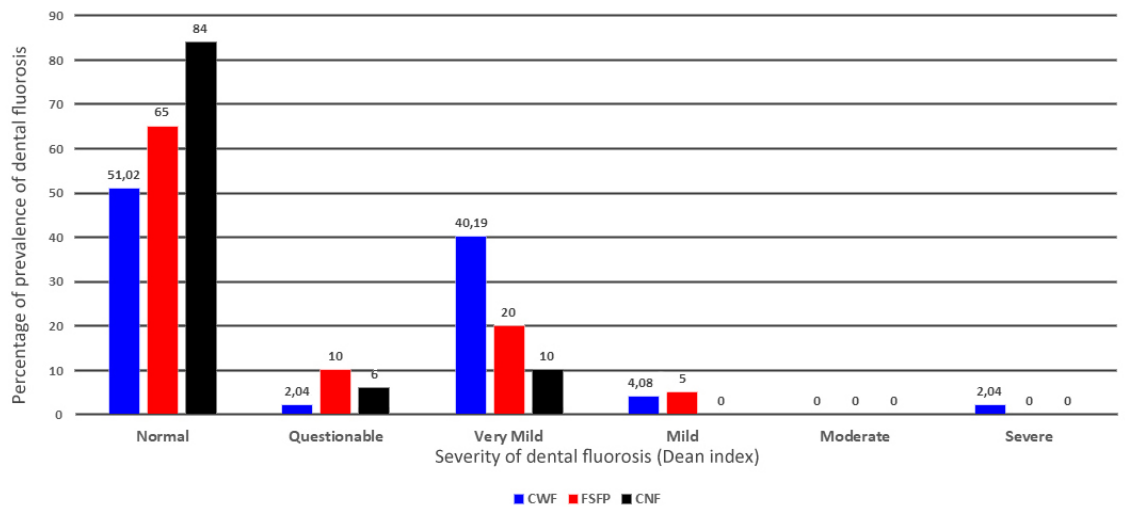

Fig. 1. Percentage of prevalence and severity of dental fluorosis in 8 years old children from 3 communities with different fluoride programs [Community with fluoridated water (CWF), community under Fluoridated School Feeding Program (FSFP) and community with no fluoride on water (CNF)].

Table I. Percentage of free-caries children and with any carious lesions and mean dmft /DMFT index per community.

\begin{tabular}{lcccc}
\hline Community & $\begin{array}{l}\text { Free-caries } \\
\text { children }\end{array}$ & $\begin{array}{l}\text { Children with } \\
\text { carious lesions }\end{array}$ & $\begin{array}{l}\text { Mean } \\
\text { dmft }\end{array}$ & $\begin{array}{c}\text { Mean } \\
\text { DMFT }\end{array}$ \\
\hline CWF & $38 \%$ & $62 \%$ & 2.14 & 0.92 \\
FSFP & $0 \%$ & $100 \%$ & 4.55 & 2.65 \\
CNF & $10 \%$ & $90 \%$ & 3.82 & 1.48 \\
\hline
\end{tabular}

Note: CWF: With Fluoridated Water / FSFP: Under Fluoridated School Feeding Program / CNF: With No Fluoridated Water

Table II. Mean of the dmft / DMFT indexes and their breakdown into their components (decayed, missing and filled).

\begin{tabular}{lclllll}
\hline Community & $\mathrm{n}$ & $\mathrm{dmft}$ & $\mathrm{d}$ & $\mathrm{m}$ & $\mathrm{f}$ & $\mathrm{SD}$ \\
\hline CWF & 50 & 2.14 & 0.54 & 0.04 & 1.58 & 2.37 \\
FSFP & 50 & 3.82 & 1.56 & 0.46 & 1.84 & 2.79 \\
CNF & 40 & 4.55 & 1.60 & 0.25 & 2.70 & 2.61 \\
\hline & $\mathrm{n}$ & $\mathrm{DMFT}$ & $\mathrm{D}$ & $\mathrm{M}$ & $\mathrm{F}$ & $\mathrm{SD}$ \\
\hline CWF & 50 & 0.92 & 0.26 & 0.66 & 0.00 & 1.45 \\
FSFP & 50 & 1.48 & 0.47 & 2.12 & 0.05 & 1.40 \\
CNF & 40 & 2.65 & 1.02 & 0.36 & 0.10 & 1.63 \\
\hline
\end{tabular}

Note: CWF: With Fluoridated Water / FSFP: Under Fluoridated School Feeding Program / CNF: With No Fluoridated Water. Includes standard deviation.

higher percentage of children with some degree of dental fluorosis, compared to the community with no fluoridated water (CNF). The highest percentage of children with no signs of dental fluorosis correlates to CNF, and compared to CFW, it has statistical significance $(p<0.05)$.

\section{DISCUSSION}

The results presented above show a considerable decrease in the prevalence of caries for the group receiving fluoridated water compared to previous studies. Urbina et al. (1996) described that only $12.6 \%$ of 6,8 and 12 yearold children were caries-free, when no fluoridated water program was established. Later, a study from Chile's Ministry of Health between 2004-2005 to assess the impact of fluoridation in the region showed a $22.26 \%$ caries-free for the population of 12 years, while for the range of 6 to 8 years it was of 25.38 $\%$ (Yévenes et al., 2011). The present study describes that the community with fluoridated water since 1996 presents $38 \%$ cariesfree in 8-year-old children, which in comparison to other communities, shows a significant decrease in dental caries for children aged 6 to 8 years, measured by the percentage of caries-free children, inferring its beneficial effect. If the overall ratio of caries-free children found in this study is compared, it can be noted that it is similar to other Latin American countries such as EI Salvador, where fluoridated water is established (Ministerio de Salud de El Salvador, 2012).

Gillcrist et al. (2001) compared fluoridated and not fluoridated 5-11 year-old children communities during 11 years in Tennessee, USA and it determined that for children with deciduous dentition from fluoridated regions, the percentage with no carious lesions was $42 \%$, while in the nonfluoridated ones it was $35 \%$ (Gillcrist et al.). Another study from 1997 associated dental caries prevalence in 8-10 year-old children from 3 different regions, 2 from Nebraska with less than $0.3 \mathrm{ppm}$ of fluoride in water and 1 from Illinois, where fluoride concentration was $1 \mathrm{ppm}$; with caries-free children the percentages were $39.8 \%, 25.2$ $\%$ and $51.9 \%$ respectively (Selwitz et al., 1988). These results are similar to those found in this study, in the sense that there is a strong difference between the values for the community with fluoridated drinking water $(38 \%)$ versus the community whose water supply is not fluoridated (10\%).

In comparison to studies made in the same region, dmft rate in 1987 was 7.01 in the 6 year-old population, in 1996 it was 
YÉVENES, I.; ZILLMANN, G.; ELLICKER, T.; ESPINOZA, P.; XAUS, G.; CISTERNAS, P.; CÁRDENAS, B. \& CASTILLO, P. Prevalence and severity of dental caries and fluorosis in 8 year-old children with or without fluoride supplementation. Int. J. Odontostomat., 13(1):46-50, 2019.

4.29, in 2005 it was 3.16 and in this study it was even lower with 2.14 in communities with fluoridated water (CFW) for 6 to 8 year-old children, attributable to the implementation and continuation of the fluoridation program on tap water. This last value is similar to those described in 1988 and 2000 in Switzerland and lower than in Spain in 1987 (Marthaler et al., 1996; Menghini et al., 2003).

In CFW, DMFT value was 0.92 and it shows a better index than previous studies like in 1987 with 3.51 , 1996 with 1.17 but it was higher than the 2005 study with 0.59. If this index is broken down, it shows that the number of decayed and missing teeth decreased from 0.37 to 0.26 and 0.007 to 0 respectively, and the increase in filled teeth is related to the establishment of the Explicit Health Guarantees Plan (Jadue et al., 2009), which covers dental care for children aged 6 in Chile. This can also explain the higher value of filled teeth on FSFP. A study of 2018, in Beirut, Lebanon, in a sample of 1433 children aged $6-8$, without fluoridated water showed caries indexes of DMFT and dmft of 0.60 and 5.15, values similar to those found in our study (Doumit \& Doughan, 2018). The Community with no fluoridated water program (CNF) had dmft value of 3.82 and DMFT of 1.48 , results which are lower and slightly higher, respectively to similar data on previous studies with no fluoride added on tap water (Urbina et al.; Yévenes et al.).

Guerrero et al. (1993) correlated severity of dental caries to the fluoride concentration in drinking water from three different cities of Chile, one with $0.19 \mathrm{ppm}$ of fluoride had a dmft of 4.7 , another with $0.88 \mathrm{ppm}$ had a dmft of 3.4 and the last with $1.2 \mathrm{ppm}$ had 1.2. In two studies in the United States, this association is also seen, rating DMFT 1.8 and 3.6 for communities with $<0.3 \mathrm{mg} / \mathrm{L}$ and $1.0 \mathrm{mg} / \mathrm{L}$ of fluoride respectively and they also reported differences of $17.7 \%$ in DMFT (Heller et al., 1997; Gillcrist et al.). Our results show that the presence of a higher concentration of fluoride in tap water produces a decrease in severity and dental caries experience. Nevertheless, it also shows an increase of dental fluorosis prevalence, which can also be seen on the population with FSFP, even though most of the cases are Very Mild in the Dean classification. Previous evidence of fluorosis in different cities with artificially and naturally fluoridated water but higher classifications can be explained by a better access and an increased exposure to fluorides by other vehicles, such as toothpastes and mouthwashes. Cases of dental fluorosis have been increasing in the last 30 years in the US, the UK and the Republic of Ireland with si- milar distribution in severity to our study, both in communities with fluoridated water and without, where infant feeding practices and the use of fluoride products by children and youth have modified the intake of this key component for the prevention of caries. It is also stated that these will continue to increase unless intervention measures are instituted and applied to the communities in our study (Fomon et al., 2000; Harding \& O'Mullane, 2013; Torjesen et al., 2014).

\section{CONCLUSION}

The contribution of fluoride in drinking water causes a decrease in the prevalence and severity of dental caries in children of 8 years of age, and an increase in the prevalence of dental fluorosis.

ACKNOWLEDGMENTS. Thanks to Fonis Health Research Project: SA 13 I20 205, Santiago - Chile. Thanks to Mr. Juan Fernández de los Ríos, from the Language and Translation services of the Faculty for kindly proofreading and checking the spelling and grammar of this article.

YÉVENES, I.; ZILLMANN, G.; ELLICKER, T.; ESPINOZA, P.; XAUS, G.; CISTERNAS, P.; CÁRDENAS, B. \& CASTILLO, P. Prevalencia y severidad de caries dental y fluorosis en niños de 8 años con o sin suplementos de flúor. Int. J. Odontostomat., 13(1):46-50, 2019.

RESUMEN: Una de las medidas más efectivas y estudiadas en la prevención de caries es el uso de fluoruros, que tiene la propiedad de reducir su incidencia y severidad. $75 \%$ de la población chilena lo recibe al incluirlo en el agua potable. La OMS en 1984 recomendó el uso de leche como un vehículo alternativo. En Chile, el Programa de Alimentación Escolar con leche fluorada fue implementado en 1994 como alternativa en zonas rurales sin fluoruro en el agua. El objetivo de este estudio fue comparar la prevalencia y severidad de la caries dental y la fluorosis dental en niños de 8 años en tres escuelas públicas, con suplementación de fluoruro en el agua potable o en la leche y con aquella que no tiene ningún programa de fluoración. Estudio epidemiológico, descriptivo, comparativo, observacional y de corte transversal con una muestra de 140 niños de 8 años, sin enfermedades sistémicas y que han vivido en el mismo lugar desde su nacimiento: 50 escolares en el área con agua fluorada, 40 en el área con leche fluorada y 50 en la zona sin suplementación de fluoruro. El porcentaje de niños libres de caries fue obtenido con la metodología descrita por la OMS, usando índices ceo-d y CPO-D para evaluar severidad. Para cuantificar la prevalencia y severidad de la fluorosis dental se ocupó el ín- 
YÉVENES, I.; ZILLMANN, G.; ELLICKER, T.; ESPINOZA, P.; XAUS, G.; CISTERNAS, P.; CÁRDENAS, B. \& CASTILLO, P. Prevalence and severity of dental caries and fluorosis in 8 year-old children with or without fluoride supplementation. Int. J. Odontostomat., 13(1):46-50, 2019.

dice de Dean. Niños libres de caries fueron $38 \%$ en la comunidad con agua fluorada (CWF); $0 \%$ en la comunidad con leche fluorada (FSFP) y $10 \%$ en la comunidad sin programa de fluoración (CNF). La diferencia entre CWF y CNF es estadísticamente significativa $(p<0,05)$. La prevalencia de fluorosis es significativamente mayor en CWF (48,8\%) que FSFP (35\%) y CNF (16\%). La contribución del fluoruro en el agua potable causa una disminución en la prevalencia y severidad de la caries dental en niños de 8 años, y un aumento en la prevalencia de fluorosis dental.

PALABRAS CLAVE: Caries Dental, Fluorosis, Niños, Suplementación Fluoruros.

\section{REFERENCES}

Carounanidy, U. \& Sathyanarayanan, R. Dental caries: A complete changeover (Part II)-Changeover in the diagnosis and prognosis. J. Conserv. Dent., 12(3):87-100, 2009.

Do, L. G.; Miller, J.; Phelan, C.; Sivaneswaran, S.; Spencer, A. J. \& Wright, C. Dental caries and fluorosis experience of 8-12-year-old children by early-life exposure to fluoride. Community Dent. Oral Epidemiol., 42(6):553-62, 2014

Doumit, M. \& Doughan, B. Dental caries and fluorosis among children in Lebanon. Indian J. Dent. Res., 29(3):317-22, 2018.

Fomon, S. J.; Ekstrand, J. \& Ziegler, E. E. Fluoride intake and prevalence of dental fluorosis: trends in fluoride intake with special attention to infants. J. Public Health Dent., 60(3):131-9, 2000.

Gillcrist, J. A.; Brumley, D. E. \& Blackford, J. U. Community fluoridation status and caries experience in children. J. Public Health Dent., 61(3):168-71, 2001.

Guerrero, R.; Cisternas, P.; Morales, H. \& Uauy, D. Prevalence of caries, oral hygiene and cariogenicity of the diet inpreschoolers and schoolchildren of cities with and without natural fluoride in their drinking water. Rev. Chil. Nutr., 21(2-3):169-75, 1993.

Harding, M. A. \& O'Mullane, D. M. Water fluoridation and oral health. Acta Med. Acad., 42(2):131-9, 2013.

Heller, K. E.; Eklund, S. A. \& Burt, B. A. Dental caries and dental fluorosis at varying water fluoride concentrations. J. Public Health Dent., 57(3):136-43, 1997

Hujoel, P. P.; Zina, L. G.; Moimaz, S. A. \& Cunha-Cruz, J. Infant formula and enamel fluorosis: a systematic review. J. Am. Dent. Assoc., 140(7):841-54, 2009.

Iheozor-Ejiofor, Z.; Worthington, H. V.; Walsh, T.; O'Malley, L.; Clarkson, J. E.; Macey, R.; Alam, R.; Tugwell, P.; Welch, V. \& Glenny, A. M. Water fluoridation for the prevention of dental caries. Cochrane Database Syst. Rev., 18(6):CD010856, 2015.

Jadue, H. L.; Delgado, B. I.; Simian, M. M. E.; Prieto, U. F.; Huberman, C. J. \& Departamento de Salud Bucal, Ministerio de Salud. Programa de salud oral integral para niños (as) de 6 años como problema de salud con garantía explícita en chile: la participación de los pediatras. Rev. Chil. Pediatr., 80(6):534-8, 2009.

Marthaler, T. M.; O'Mullane, D. M. \& Vrbic, V. The prevalence of dental caries in Europe 1990-1995. ORCA Saturday afternoon symposium 1995. Caries Res., 30(4):237-55, 1996.

McLaren, L.; Patterson, S.; Thawer, S.; Faris, P.; McNeil, D.; Potestio, M. L. \& Shwart, L. Exploring the short-term impact of community water fluoridation cessation on children's dental caries: a natural experiment in Alberta, Canada. Public Health, 146:56-64, 2017.

Menghini, G.; Steiner, M.; Marthaler, T.; Helfenstein, U.; Brodowski, D.; Imfeld, C.; Weber, R. \& Imfeld, T. Caries prevalence among students in 16 Zurich districts in the years 1992 to 2000. Schweiz. Monatsschr. Zahnmed., 113(3):267-77, 2003.
Ministerio de Salud (MINSAL). Análisis de Situación de Salud Bucal en Chile. Santiago de Chile, Ministerio de Salud, Gobierno de Chile, 2010. Available from: https://www.minsal.cl/sites/default/files/files/An \%C3 $\%$ A1lisis \%20de \%20Situaci \%C3 \%B3n \%20Salud \%20Bucal \%20final \%20pdf.pdf

Ministerio de Salud (MINSAL). Norma de Uso de Fluoruros en la Prevención Odontológica. Santiago de Chile, Ministerio de Salud, Gobierno de Chile, 2008. Available from: http://www.enfermeriaaps.com/portal/ ?wpfb $\mathrm{dl}=3928$

Ministerio de Salud de El Salvador. Diagnóstico Nacional de Salud Bucal. San Salvador, Ministerio de Salud de El Salvador, 2012. Available from: http://asp.salud.gob.sv/regulacion/pdf/otrosdoc/ diagnostico nacional_salud_bucal.pdf

Otten, J. J.; Hellwig, J. P. \& Meyers, L. D. DRI. Dietary Reference Intakes. The Essential Guide to Nutrient Requirements. Washington D. C., National Academy Press, 2006. pp.312-9.

Quock, R. L. Dental caries: a current understanding and implications. J. Nat. Sci., 1(1):e27, 2017

Romero, V.; Norris, F. J.; Ríos, J. A.; Cortés, I.; González, A.; Gaete, L. \& Tchernitchin, A. N. Consecuencias de la fluoración del agua potable en la salud humana. Rev. Med. Chile, 145:240-9, 2017.

Selwitz, R. H.; Nowjack-Raymer, R. E.; Kingman, A. \& Driscoll, W. S. Dental caries and dental fluorosis among schoolchildren who were lifelong residents of communities having either low or optimal levels of fluoride in drinking water. J. Public Health Dent., 58(1):28-35, 1988.

Torjesen, I. Water fluoridation almost halves hospital admissions for dental caries, report finds. B. M. J., 348:g2394, 2014.

U.S. Department of Health and Human Services Federal Panel on Community Water Fluoridation. U.S. Public Health Service Recommendation for Fluoride Concentration in Drinking Water for the Prevention of Dental Caries. Public Health Rep., 130(4):318-31, 2015.

Urbina, T.; Caro, J. C. \& Vicent, M. Caries Dentaria y Fluorosis en niños de 6 a 8 y 12 años, de la II, VI, VIII, IX, X, y Región Metropolitana. Santiago de Chile, Ministerio de Salud, Gobierno de Chile, 1996.

World Health Organization (WHO). Oral Health Surveys: Basic Methods. $5^{\text {th }}$ ed. Geneva, World Health Organization, 2013.

Yeung, C. A. Fluoride prevents caries among adults of all ages. Evid. Based Dent., 8(3):72-3, 2007.

Yévenes, I.; Zillmann, G.; Muñoz, A.; Aranda, W.; Echeverría, S.; Hassi, J.; Maass, P.; Salazar, M. \& MINSAL: Chilean Health Ministry Caries and fluorosis in the Santiago metropolitan region in Chile: The impact of the fluoridation of the water. Rev. Odonto Cienc., 26(2):109-15, 2011.

Zanella-Calzada, L. A.; Galván-Tejada, C. E.; Chávez-Lamas, N. M.; Gracia-Cortés, M. D. C.; Moreno-Báez, A.; Arceo-Olague, J. G.; CelayaPadilla, J. M.; Galván-Tejada, J. I. \& Gamboa-Rosales, H. A case_control study of socio-economic and nutritional characteristics as determinants of dental caries in different age groups, considered as public health problem: data from NHANES 2013_2014. Int. J. Environ. Res. Public Health, 15(5):E957, 2018.

Corresponding author:

Dr. Ismael Yévenes López

University of Chile

Faculty of Dentistry

Institute for Research in Dental Sciences

Sergio Livingstone 943

Independencia

Santiago - CHILE

E-mail: iyevenes@odontologia.uchile.cl

Received: 06-08-18

Accepted: $19-10-18$ 